\title{
Porous Biodegradable Metals for Hard Tissue Scaffolds: A Review
}

\author{
A. H. Yusop, A. A. Bakir, N. A. Shaharom, M. R. Abdul Kadir, and H. Hermawan \\ Medical Implant Technology Group (MediTeg), Faculty of Health Science and Biomedical Engineering, Universiti Teknologi Malaysia, \\ 81310 Johor Bahru, Malaysia
}

Correspondence should be addressed to H. Hermawan, hendra.hermawan@biomedical.utm.my

Received 16 March 2012; Accepted 5 June 2012

Academic Editor: Giovanni Vozzi

Copyright (c) 2012 A. H. Yusop et al. This is an open access article distributed under the Creative Commons Attribution License, which permits unrestricted use, distribution, and reproduction in any medium, provided the original work is properly cited.

Scaffolds have been utilized in tissue regeneration to facilitate the formation and maturation of new tissues or organs where a balance between temporary mechanical support and mass transport (degradation and cell growth) is ideally achieved. Polymers have been widely chosen as tissue scaffolding material having a good combination of biodegradability, biocompatibility, and porous structure. Metals that can degrade in physiological environment, namely, biodegradable metals, are proposed as potential materials for hard tissue scaffolding where biodegradable polymers are often considered as having poor mechanical properties. Biodegradable metal scaffolds have showed interesting mechanical property that was close to that of human bone with tailored degradation behaviour. The current promising fabrication technique for making scaffolds, such as computation-aided solid freeform method, can be easily applied to metals. With further optimization in topologically ordered porosity design exploiting material property and fabrication technique, porous biodegradable metals could be the potential materials for making hard tissue scaffolds.

\section{Introduction}

One of the most attractive subjects in tissue engineering is the development of a scaffold, a three-dimensional porous solid structure that plays a key role in assisting tissue regeneration [1]. Ideally, a scaffold must be porous, bioactive, and biodegradable and possess adequate mechanical properties suited to the biological site. Sufficient porosity is needed to accommodate cell proliferation and differentiation, which will eventually enhance tissue formation $[2,3]$. It is also desirable for a scaffold to have high interconnectivities between pores for uniform cell seeding and distribution, and for the nutrients and metabolites exchange at the cell/scaffold construct [4-6]. A bioactive scaffold promotes cell-biomaterial interactions, cell proliferation, adhesion growth, migration, and differentiation. It also promotes extracellular matrix (ECM) deposition and permits transportation for nutrient and gases and waste removal for cell survival [2]. A biodegradable scaffold allows the replacement of biological tissues via physiological extracellular components without leaving toxic degradation products. Its degradation rate should match the rate of new tissue regeneration in order to maintain the structural integrity and to provide a smooth transition of the load transfer from the scaffold to the tissue [3]. Finally, as a mechanical support, a scaffold must possess adequate mechanical stability to withstand both the implantation procedure and the mechanical forces that are typically experienced at the scaffold-tissue interface and does not collapse during patient's normal activities [3]. Mechanically, the major challenge is to achieve adequate initial strength and stiffness and to maintain them during the stage of healing or neotissues generation throughout the scaffold degradation process $[3,7,8]$.

Biodegradable polymers have been widely used and accepted as the most suitable materials for scaffolds due to their degradability, biocompatibility, and ease of processability [9-11]. Synthetic biodegradable polymers such as poly(lactic acid) (PLA), poly(glycolic acid) (PGA), and their copolymers have been used in many clinical applications [12-16]. Biodegradable polymers degrade through hydrolysis process and are gradually absorbed by the human body thus allowing the supported tissue to gradually recover its functionality $[8,17]$. Biodegradability can be imparted into polymers through molecular design with a controlled rate 

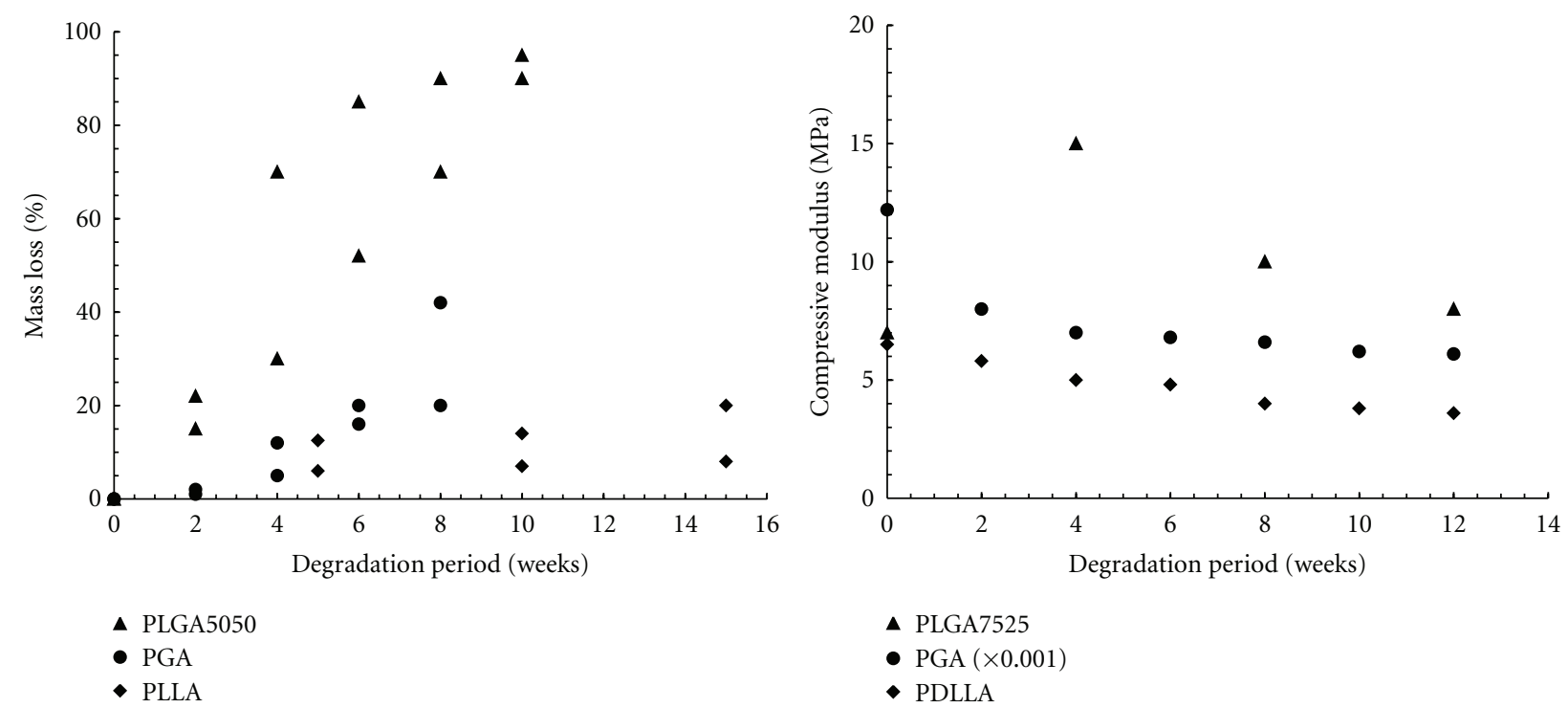

\ PLGA5050

- PGA

- Plla

Figure 1: Mass loss and strength retention of some polymers used for scaffolds. Data compiled from [42-49].

in concert with tissue regeneration [18-21]. For instance, PLA could be combined with PGA to form poly(lactic-coglycolic acid) (PLGA), which has degradation rate tailored with the tissue healing period and has been shown to support osteoblast cells attachment and growth in vitro and in vivo [22-24]. Beside copolymerization, polymer composites have been explored in order to improve mechanical property and biocompatibility. Zhang and Ma have developed [25] a highly porous biodegradable polymer/apatite composite scaffold (95\% porosity) through a thermally induced phase separation technique, which resulted in significant improvement in mechanical properties compared to polymer-only scaffold. The work by Ma et al. [26] has shown that osteoblast survival and growth were significantly enhanced in the PLLA/HA composite scaffolds compared to the plain PLLA scaffolds.

One of the major concerns regarding the use of biodegradable polymers as scaffold is their poor mechanical properties [27]. For hard tissue applications such as bone, a scaffold that possesses adequate strength and Young's modulus is desirable. However, porous polymeric structures are relatively weak and may not achieve sufficient level of the required strength $[8,27]$. During degradation, polymers could suddenly lose their mass and mechanical integrity. Figure 1 illustrates mass loss and strength retention as the function of degradation period for some biodegradable polymers used for scaffold.

There is a recent and fast-growing interest in the use of biodegradable metals for biomedical applications [28]. The inherent strength and ductility owned by metals are the key features that make them appealing for hard tissue applications. Magnesium- (Mg-) based and iron- (Fe-) based metals have been used, which include Mg-RE (rare earth elements) [29-33], Mg-Ca- [34, 35], pure Fe [36, 37], Fe-Mn alloys [38, 39], and Fe foam for bone replacement scaffold [40]. $\mathrm{Mg}$ and its alloys have been proposed for orthopaedic implants due to their supportive physical properties to human bones. It has a density closer to that of natural bones $\left(1.8-2 \mathrm{~g} / \mathrm{cm}^{3}\right)$ and has been reported to support the activation of bone cells [41]. Mg degrades in vivo through electrochemical process, which produces $\mathrm{Mg}$ hydroxide and hydrogen gas. Combining their excellent mechanical properties and degradability, $\mathrm{Mg}$ and its alloys are now viewed as a potential alternative for making scaffold for tissue regeneration application. Therefore, this paper aims to review the potentiality of porous biodegradable metals as material for hard tissue scaffold. Elaborations to their rationale, structure, mechanical properties, degradation, and fabrication method are presented.

\section{Porous Mg as Scaffold Material}

2.1. Rationale. $\mathrm{Mg}$ is largely found in bone tissue, it is an essential element to human body, and its presence is beneficial to bone growth and strength [52-54]. It is a cofactor for many enzymes and serves as stabilizer of DNA and RNA structures [55]. With approximately half of the total estimated $25 \mathrm{~g}$ content stored in bone tissue, $\mathrm{Mg}$ is the fourth most abundant cation in the human body [56, 57]. In the extracellular fluid, the level of $\mathrm{Mg}$ ranges between 0.7 and $1.05 \mathrm{mmol} / \mathrm{L}$, and its homeostasis is maintained by the intestine and kidneys $[52,53]$. The incidence of hyper-Mg is rare due to the efficient excretion of the element in the urine $[52,56]$.

$\mathrm{Mg}$ can be considered as osteoconductive and bone growth stimulator material as suggested by many studies. A significant increase of bone area has been observed in $\mathrm{Mg}$ based implants compared to those based on PLA [41, 58]. The corrosion layer around $\mathrm{Mg}$ implants has been observed to contain calcium phosphates, which appeared to be in direct contact with the surrounding bone [41]. Xu et al. 
have shown [59] new bone formation around Mg-Mn- Zn implants in their in vivo degradation in rats. Witte et al. observed [60] that 3 months postoperatively, open porous Mg scaffolds implanted in rabbits were largely degraded, foreign body giant cells phagocytizing the remaining corrosion products were rarely found, and no osteolytic changes were found around the implant site. It has been shown that porous $\mathrm{Mg}$ has better degradation behavior in terms of lower $\mathrm{pH}$ change, slower hydrogen evolution, and slower decrement of compressive yield strength in simulated body fluid (SBF) immersion tests [61]. Zreiqat et al. reported [62] an increasing bone cell adhesion on Mg-enriched alumina as expressed by enhanced level of a5b1 integrin receptor and collagen extracellular matrix protein. Two studies using Mg-enriched apatites or collagen materials showed good biocompatibility on bone cell attachment and tissue growth $[63,64]$.

$\mathrm{Mg}$ and its alloys are very lightweight metals having density ranging from 1.74 to $2.0 \mathrm{~g} / \mathrm{cm}^{3}$, which is less than that of Ti alloys $\left(4.4-4.5 \mathrm{~g} / \mathrm{cm}^{3}\right)$ and is close to that of bone $\left(1.8-2.1 \mathrm{~g} / \mathrm{cm}^{3}\right)$ [65]. They have a wide range of elongation and tensile strength from $3 \%$ to $21.8 \%$ and from 86.8 to $280 \mathrm{MPa}$, respectively. $\mathrm{Mg}$ possess a greater fracture toughness compared to that of ceramic biomaterials, and its elastic modulus (41-45 GPa) is closer to that of the bone compared to other metals. This property could play a vital role in avoiding the stress shielding effect. $\mathrm{Mg}$ also has better ductility than synthetic hydroxyapatite and higher strength than existing biodegradable polymers [66]. Table 1 shows the mechanical properties of pure $\mathrm{Mg}$ compared to other metals and to bones. The elastic modulus of pure $\mathrm{Mg}$ is closer to that of cortical and cancellous bones, which is a superior feature for bone scaffolds. Mechanical property of $\mathrm{Mg}$ can be further improved by alloying and thermomechanical processes. Addition of alloying elements such as aluminium, silver, indium, silicon, tin, zinc, and zirconium could improve both the strength and elongation of $\mathrm{Mg}$ alloys [67]. Moreover, some manufacturing processes such as hot rolling, hot extruding, and equal-channel angular pressing (ECAP) could also contribute to the strength of $\mathrm{Mg}$ alloys and in some cases also improve ductility [67-69].

2.2. Degradation Behavior of $M g$. In physiological saline environment, $\mathrm{Mg}$ and its alloys degrade through the following electrochemical (corrosion) process $[65,74]$ :

$$
\begin{gathered}
\mathrm{Mg}(\mathrm{s})+2 \mathrm{H}_{2} \mathrm{O} \longrightarrow \mathrm{Mg}(\mathrm{OH})_{2}(\mathrm{~s})+\mathrm{H}_{2}(\mathrm{~g}) \\
\mathrm{Mg}(\mathrm{s})+2 \mathrm{Cl}^{-}(\mathrm{aq}) \longrightarrow \mathrm{MgCl}_{2} \\
\mathrm{Mg}(\mathrm{OH})_{2}(\mathrm{~s})+2 \mathrm{Cl}^{-}(\mathrm{aq}) \longrightarrow \mathrm{MgCl}_{2}+2 \mathrm{OH}^{-}(\mathrm{aq})
\end{gathered}
$$

In the first reaction, gray $\mathrm{Mg}(\mathrm{OH})_{2}$ film is developed on the surface of $\mathrm{Mg}$ as it reacts with water and hydrogen bubbles are also produced. The metal can also directly react with chloride ions to form $\mathrm{Mg}$ chloride (2). This highly soluble $\mathrm{MgCl}_{2}$ is also formed through the reaction of $\mathrm{Mg}(\mathrm{OH})_{2}$ with chloride ions, as depicted in (3) [75]. Unfortunately, pure $\mathrm{Mg}$ corrodes very quickly in physiological solution.

\begin{tabular}{|c|c|c|c|c|}
\hline Tissue/material & $\begin{array}{l}\text { Density } \\
\left(\mathrm{g} / \mathrm{cm}^{3}\right)\end{array}$ & $\begin{array}{l}\text { Ultimate } \\
\text { tensile strength } \\
(\mathrm{MPa})\end{array}$ & $\begin{array}{c}\text { Yield } \\
\text { strength } \\
(\mathrm{MPa})\end{array}$ & $\begin{array}{c}\text { Elastic } \\
\text { modulus } \\
(\mathrm{GPa})\end{array}$ \\
\hline $\begin{array}{l}\text { Cortical bone } \\
{[70]}\end{array}$ & $1.8-2.0$ & $35-283$ & $104.9-114.3$ & $5-23$ \\
\hline $\begin{array}{l}\text { Cancellous } \\
\text { bone [70] }\end{array}$ & $1.0-1.4$ & $1.5-38$ & - & $\begin{array}{c}10-1570 \\
(\mathrm{MPa})\end{array}$ \\
\hline Ti6Al4V [70] & 4.43 & $830-1025$ & $760-880$ & 114 \\
\hline $\begin{array}{l}\text { 316L stainless } \\
\text { steel [71] }\end{array}$ & 8.0 & $450-650$ & $200-300$ & 190 \\
\hline $\begin{array}{l}\text { Pure Mg, } \\
\text { annealed [72] }\end{array}$ & 1.74 & 160 & 90 & 45 \\
\hline $\begin{array}{l}\text { WE43 Mg } \\
\text { alloy, T6 [73] }\end{array}$ & 1.84 & 220 & 170 & 44 \\
\hline
\end{tabular}

TABLE 1: Mechanical properties of $\mathrm{Mg}$ compared to bone and metals.

This may cause Mg implant to lose its mechanical integrity before the tissue is completely healed. Moreover, its corrosion reaction produces hydrogen gas at a rate that is too high to be dealt with by the host tissue [41, 76, 77]. This issue, along with the development of stainless steels in 1920s [41] led to the abandonment of $\mathrm{Mg}$ in spite of some early successful implantation results $[76,78,79]$.

As the science and technology of $\mathrm{Mg}$ processing advances, many improvements have been reported to corrosion resistance as well as to mechanical properties of its alloys. As an example, Stroganov et al. reported [80] that Mg alloyed with $0.4-4 \mathrm{wt} \%$ REs, and other trace elements such as $\mathrm{Cd}$ and $\mathrm{Al}$, had a slowed corrosion rate, where $3 \mathrm{~mm}$ diameter pins resided for 5 months, and those $8 \mathrm{~mm}$ in diameter resided for 11 months in vivo. Table 2 summarizes some reports on various treatments to $\mathrm{Mg}$ and its alloys for biomedical applications.

2.3. Porous Structure of $\mathrm{Mg}$. Some early studies have shown the necessity for a porous structure in bone regeneration. Kuboki et al. have shown [89] that direct osteogenesis had taken place in the porous particles of hydroxyapatite rather than the solid particles in rat ectopic model. Titanium implants recovered from sheep tibiae showed enhanced cortical shear strength from porous titanium coating, while further coating with hydroxyapatite beads did not result in significant improvement [90].

Although porosity will diminish the bulk properties of a material, porous $\mathrm{Mg}$ still has the strength and stiffness in close range to that of native bone. The effects of porosity and pore size on the mechanical properties of porous $\mathrm{Mg}$ scaffolds have been investigated [91, 92] and the results indicated that yield, compressive, and flexural strength as well as Young's modulus decreased with both the pore volume, and size. Pore morphology, volume and size can significantly affect the mechanical properties of porous Mg materials [91, 93, 94]. However, this is not critical for $\mathrm{Mg}$ scaffolds since their mechanical properties are still comparable to bone $[95,96]$. The lower limit of bone strength is about $3 \mathrm{MPa}$ [97], whilst the compressive strength 
TABLE 2: Reports on corrosion resistance of Mg and its alloys.

Material and method
Calcium addition to AZ91Ca (1 wt $\%)$ and
AZ61 (0.4 wt $\%)$ alloys [81]

Mg-Mn and Mg-Mn-Zn alloys [82]

Alkaline heat treatment on $\mathrm{Mg}-\mathrm{Ca}$ alloy [83]

$\mathrm{MgF}_{2}$ coating on extruded LAE442 alloy [84]

Hydroxyapatite coating on AZ91 alloy [85]

Hydroxyapatite coating with $\mathrm{MgF}_{2}$ interlayer on pure $\mathrm{Mg}$ [86]

Phosphating treatment to form brushite layer on extruded Mg-Mn-Zn alloy $[81,87]$

Chitosan coating on Mg-1Ca alloy [88]
Findings

The high amount of $\mathrm{Ca}$ in the alloy enhanced the formation of calcium phosphate on the surface and improved corrosion resistance; there was only a slight decrease in mechanical property of the alloy in SBF as compared to that of in air

Addition of $\mathrm{Mn}$ and $\mathrm{Zn}$ elements accelerated the formation of Mg-containing phosphate and provided better protection for matrix alloy; Zn-containing phosphate layer provided an effective protection to the alloy

Corrosion rates of treated alloy in SBF were decreased; the treated alloy samples did not induce toxicity to L-929 cells during 7 days of culture

Extruded LAE442 alloy provided low corrosion rates and reacts in vivo with an acceptable host response; localized corrosion attack was observed in both coated and uncoated LAE442 implants

The coated alloy showed $20 \%$ improvement in the mechanical strength as compared to that of the uncoated one; $40 \%$ loss in the mechanical strength after 5 days of exposure to $\mathrm{SBF}$ was measured for the uncoated alloy

Coated Mg corroded less than bare Mg and showed an effective protection from in vivo corrosion; coated $\mathrm{Mg}$ had a higher bone-to-implant contact ratio in the cortical bone area of the rabbit femora 4 weeks after implantation

Electrochemical and immersion tests showed that the brushite $\left(\mathrm{CaHPO}_{4} \cdot 2 \mathrm{H}_{2} \mathrm{O}\right)$ coating provided a good protection against corrosion in SBF; corrosion resistance increased with the increase of the phosphating time within $50 \mathrm{~min}$

Corrosion resistance of the coated alloy in SBF was improved and Young's modulus of cancellous bone are $0.2-80 \mathrm{MPa}$ and $0.01-2 \mathrm{GPa}$, respectively [98]. Hence, the range of bone stiffness and strength may be achieved by $\mathrm{Mg}$ scaffolds by modulating their porosity and pore sizes. Porosity also eventually decreases corrosion resistance of porous Mg. Zhuang et al. had evaluated [92] in vitro degradation behavior of two different $\mathrm{Mg}$ porosities in physiological saline solution $(0.9 \%$ $\mathrm{NaCl}$ ). The specimens with $55 \%$ porosity degraded faster than those with $36 \%$ porosity due to more connecting areas and transport channels for the solution to perform faster chemical reactions.

Porous architecture of $\mathrm{Mg}$ scaffold has been proven to play a significant role in cell growth and proliferation. Tan et al. reported [50] their work on three-dimensional opencellular $\mathrm{Mg}$ structure fabricated by mechanical perforation method. By using the Taguchi method, they concluded an optimum pore configuration at $70 \%$ porosity, $300 \mu \mathrm{m}$ pore size, and $90^{\circ}$ pore arrangement angle whereas these three parameters had different effects on the compressive properties. Pore distribution also influences rabbit cranial bone ingrowth behavior as proved by Simon et al. [99]. They observed a continuous ingrowth in the random pore size scaffolds from the outer periphery; meanwhile, for the same sized pores and solid walls scaffolds, discontinuous ingrowth with bone islands throughout the whole scaffold was observed.

2.4. Fabrication of Porous $\mathrm{Mg}$. In the recent years, synthesis of cellular metals having open or closed pores of either periodic or random pore topology has been extensively studied. Periodic structure offers advantages over random architectures in designing better mechanical efficiency and function [100]. There have been various routes to modulate the periodic structure topology to satisfy a range of applications including biomedical implants [101].

Random cellular $\mathrm{Mg}$ can be fabricated via powder or chip sintering (conventional, laser assisted, or spark plasma), low pressure casting, or removable spacer methods. These fabrication routes generate a random cell structure, wide distributions of cell size, and morphology leading to unpredictable material properties over the range of hundred microns [102, 103]. Processes that can be used to fabricate $\mathrm{Mg}$ with topologically ordered open cell structure include solid free-form process, space holder method, leaching method, replication, electrodeposition, and vapor deposition. Figure 2 shows example of porous $\mathrm{Mg}$ scaffolds made by two different processes.

2.4.1. Solid Free-Form Process. This technique encompasses rapid prototyping and casting processes, where a step-bystep fabrication process from computer-aided design (CAD) models is adopted. It is currently an ideal solution for manufacturing complex $3 \mathrm{D}$ porous structures by accurate controlling of the structure topology [104]. The six basic steps in the synthesis of a topologically ordered porous $\mathrm{Mg}$ (TOPM) are (1) creating a 3D model with the desired architecture using CAD; (2) printing a positive polymeric template of the model by rapid prototyping (RP) process; (3) infiltrating the polymeric template with a $\mathrm{NaCl}$ paste; (4) removing the template by heating followed by sintering of $\mathrm{NaCl}$; (5) casting liquid $\mathrm{Mg}$ into $\mathrm{NaCl}$ template, that is, with pressure assistance; (6) removing $\mathrm{NaCl}$ template by dissolution $[51,105]$. 


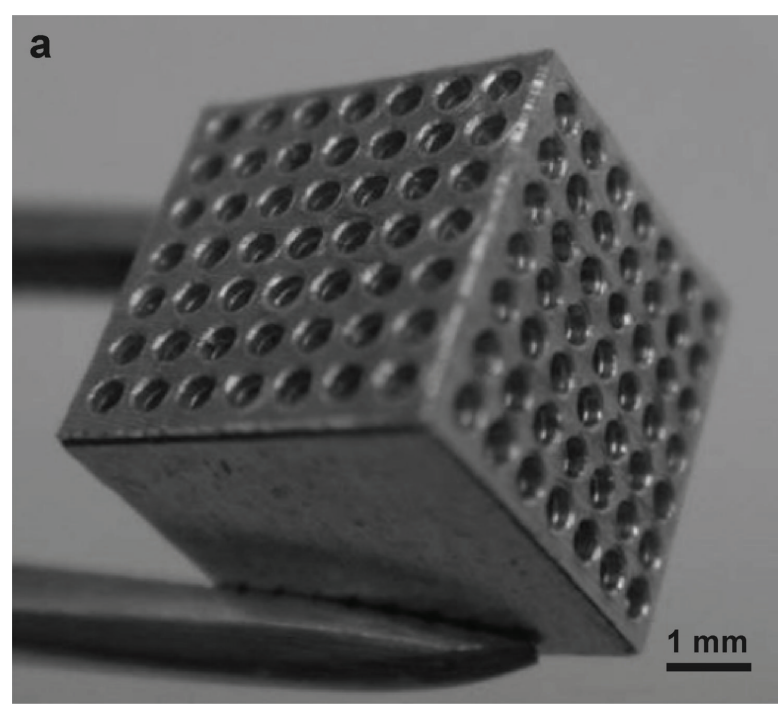

(a)

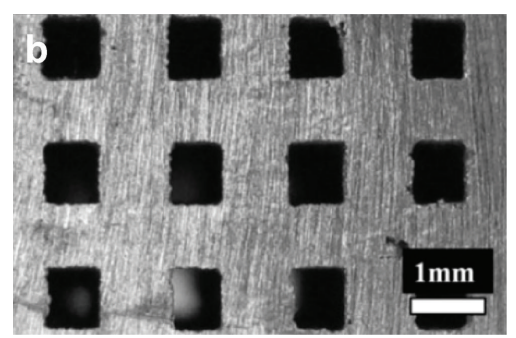

(b)

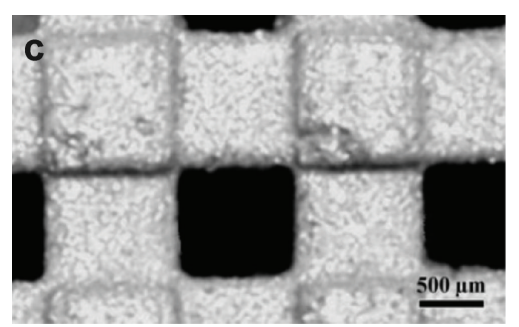

(c)

FIGURE 2: Example of porous Mg scaffolds: (a) made by laser-assisted mechanical perforation technique, adapted with permission from IOP [50]; (b, c) made by solid free-form fabrication method, adapted with permission from John Wiley and Sons [51].

This technique gives several advantages including the ease of providing considerable high surface area of scaffold, which is essential for cell growth and cell proliferation: also no toxic solvent is involved in the process. Staiger et al., one of the pioneers in this technique, achieved [105] high replication accuracy with a resolution of $0.8 \mathrm{~mm}$ and errors of $5 \sim 12 \%$ for their porous Mg. Kirkland et al. reported [106] their capability to create square pores with a size of at least $0.3 \mathrm{~mm} \times 0.3 \mathrm{~mm}$, and Witte et al. produced [107] open porous Mg scaffolds with 72 to $76 \%$ porosity and pore sizes ranging between 10 and $1000 \mu \mathrm{m}$, and tested into the patellar cartilage of rabbits where new bone formation was observed.

Precautions should be taken during the removal process of $\mathrm{NaCl}$ from the cast $\mathrm{Mg}$ structure. The remaining salt will dissolve into aqueous solution and aggressive chloride ions will increase $\mathrm{Mg}$ corrosion [108-110]. Hence, only fresh $\mathrm{NaOH}$ solution should be used to dissolve $\mathrm{NaCl}$ to reduce the buildup of chloride ions. Overinfiltrating, partially infiltrating, and underinfiltrating should be avoided so as to obtain a perfect replicate casting of 3D CAD model [51]. It should be noted also that molten $\mathrm{Mg}$ at high pressure will infiltrate not only pores of the $\mathrm{NaCl}$ mould, but also the micropores between sintered $\mathrm{NaCl}$ particles, resulting in the impossibility of the removal of all residual $\mathrm{NaCl}$ from the structure.

Challenge in this technique includes dimensional change from polymer model to $\mathrm{NaCl}$ template to $\mathrm{Mg}$ structure. Nguyen et al. reported [51] dimensional change between 0.3 and $0.4 \mathrm{~mm}$ for strut sizes converted from RP model to $\mathrm{NaCl}$ template as a result of low filling efficiency during $\mathrm{NaCl}$ infiltration process. The difficulty to infiltrate occurred at pore sizes smaller than $0.8 \mathrm{~mm}$. It was also identified that the use of $\mathrm{NaCl}$ is limited by the strength or fragility of the sintered $\mathrm{NaCl}$ template, which then limits casting capability. The use of larger $\mathrm{NaCl}$ particle distribution size (i.e., from 20 to $65 \mathrm{~mm}$ ) has been suggested to improve the flow of $\mathrm{NaCl}$ paste and the strength of sintered template. Resolution of the RP printer is also another limitation to produce finer structures at a size similar to the hierarchical structure of human bone.

2.4.2. Space Holder, Leaching, and Other Potential Methods. The limitation in obtaining homogenous pore size by powder metallurgical method can be solved by the use of space holder materials [91-93]. As an example, carbamide $\left(\mathrm{CO}\left(\mathrm{NH}_{2}\right)_{2}\right)$ has been used as a spacer material to fabricate porous structures of pure $\mathrm{Mg}$ [92]. The process produced open-cellular Mg (porosities: $36-55 \%$; pores: $200-$ $400 \mu \mathrm{m}$ ) having mechanical properties close to that of natural bone. The leaching method has been applied to produce porous Mg-calcium-phosphate (MCP), where macropores and micropores were created by $\mathrm{NaCl}$ particles and saturated $\mathrm{NaCl}$ solution, respectively [111]. Other potential methods are electrodeposition and vapor deposition. Electrodeposition involves the use of metallic ions solution to deposit metallic elements on electrically conductive polymeric foam [112]; meanwhile vapor deposition uses chemical reactants in gaseous phase, which were heated by radiation prior to their deposition on polymeric precursor substrate [113].

\section{Porous Fe as Scaffold Material}

Fe is an essential element that plays significant roles in human body metabolism including transport, activation, and storage of molecular oxygen, reduction of ribonucleotides and dinitrogen [114], and decomposition of lipid, protein, and DNA damages [115]. Fe has a higher elastic modulus $(211 \mathrm{GPa})$ compared to that of $\mathrm{Mg}(41 \mathrm{GPa})$ and its alloys (44 Gpa) and 316L stainless steel (190 Gpa) [116, 117]. Peuster et al. are among the first who proposed [36] Fe as a biodegradable metal, where they reported an in vivo 
implantation test of Fe stents in the descending aorta of rabbits. They showed evidence that pronounced inflammatory response and systemic toxicity were not observed up to 18 months of the study.

Currently, there is limited literature on Fe as a scaffold material. Very recently, Farack et al. have studied [40] Fe foam coated with calcium-phosphate for bone replacement scaffold where human mesenchymal stem cells proliferated and differentiated more on coated Fe foams than on uncoated ones. The coating gave enhanced bioactivity and inhibited degradation of Fe foams; however, the latest is actually questionable since Fe was generally viewed as having too slow degradation for implant applications [118]. The open porous Fe and Fe-phosphorous alloys have been investigated as biodegradable bone replacement [119], and the results showed that addition of phosphorus increased compressive yield up to $11 \mathrm{MPa}$, higher than that of pure $\mathrm{Fe}$ of 2.4 MPa, and resulted in a Young's modulus of $2.3 \mathrm{GPa}$ which is comparable to that of typical bone. The alloys showed also faster in vitro degradation than pure Fe but still considered slow as large fraction of material was observed during 12 months in vivo study [119]. Nevertheless, alloying Fe with phosphorous seems to be a promising way to optimize both mechanical and degradation properties of Fe especially for bone scaffold.

Porous $\mathrm{Fe}$ has been fabricated via several methods including solid-gas eutectic solidification process [120, 121], $\mathrm{CO}-\mathrm{CO}_{2}$ gas foaming powder metallurgy process [122], or powder metallurgy with the use of polymer foaming agent $[119,123]$, or even using wood as template [124]. However, those techniques hardly provide the topologically ordered porous as desired for bone scaffold. Moreover, owing to its very high melting temperature, the solid free-form method as applied to $\mathrm{Mg}$ seems to be nonapplicable for Fe where the excessive heat might destruct the $\mathrm{NaCl}$ template.

\section{Perspective}

Biodegradable metals as tissue scaffolding materials have been viewed as alternative to polymers for hard tissue regeneration exploiting mostly their superior mechanical properties over biodegradable polymers. Biodegradable metals such as $\mathrm{Mg}$ and its alloys possess mechanical properties in close range to those of native human bone and have shown encouraging results when used as tissue scaffolds. Porous Fe could also be viewed as a potential scaffold material but available data is scarce especially in its relation to bone tissue. Among many promising techniques to fabricate metal scaffolds, solid free-form is currently viewed as the most potential method to fabricate biodegradable metal scaffolds having optimized pore morphology for cell growth and cell proliferation. This technique permitted the design and realization of topologically ordered porous $\mathrm{Mg}$ with periodic structure for enhanced mechanical efficiency and function of a porous scaffold. Further investigations are needed in the solid free-form fabrication method to develop a scaffold with properties specifically tailored for cell regeneration and tissue growth.
Overall, application of biodegradable metals for tissue engineering scaffold is just in the beginning. Limited work has been done and much has still is to be done. The directions could be in finding suitable process for making porous structure from all prospective biodegradable metals, understanding the influence of porous structure to mechanical and degradation properties, and understanding the cell regeneration and degradation product transport in the porous structure. Integrating biodegradable polymers or ceramics and drugs could be another interesting direction to explore.

\section{Acknowledgments}

This work was supported by the Malaysian Ministry of Higher Education (MOHE) and Universiti Teknologi Malaysia (UTM) through research grants Q.J130000.7136.00H54 (Tier-1) and J.130000.7836.4L019 (ERGS).

\section{References}

[1] D. Brahatheeswaran, Y. Yasuhiko, M. Toru, and K. D. Sakthi, "Polymeric scaffolds in tissue engineering application: a review," International Journal of Polymer Science, vol. 2011, Article ID 290602, 19 pages, 2011.

[2] C. H. Chang, F. H. Lin, T. F. Kuo, and H. C. Liu, "Cartilage tissue engineering," Biomedical Engineering: Applications, Basis and Communications, vol. 17, pp. 1-11, 2005.

[3] M. V. Risbud and M. Sittinger, "Tissue engineering: advances in in vitro cartilage generation," Trends in Biotechnology, vol. 20, no. 8, pp. 351-356, 2002.

[4] M. Gravel, T. Gross, R. Vago, and M. Tabrizian, "Responses of mesenchymal stem cell to chitosan-coralline composites microstructured using coralline as gas forming agent," Biomaterials, vol. 27, no. 9, pp. 1899-1906, 2006.

[5] D. W. Hutmacher, M. Sittinger, and M. V. Risbud, "Scaffoldbased tissue engineering: rationale for computer-aided design and solid free-form fabrication systems," Trends in Biotechnology, vol. 22, no. 7, pp. 354-362, 2004.

[6] D. W. Hutmacher, T. Schantz, I. Zein, K. W. Ng, S. H. Teoh, and K. C. Tan, "Mechanical properties and cell cultural response of polycaprolactone scaffolds designed and fabricated via fused deposition modeling," Journal of Biomedical Materials Research, vol. 55, pp. 203-216, 2001.

[7] J. Bonadio, E. Smiley, P. Patil, and S. Goldstein, "Localized, direct plasmid gene delivery in vivo: prolonged therapy results in reproducible tissue regeneration," Nature Medicine, vol. 5, no. 7, pp. 753-759, 1999.

[8] H. Y. Cheung, K. T. Lau, T. P. Lu, and D. Hui, "A critical review on polymer-based bio-engineered materials for scaffold development," Composites Part B, vol. 38, no. 3, pp. 291-300, 2007.

[9] G. Chen, T. Ushida, and T. Tateishi, "Scaffold design for tissue engineering," Macromolecular Bioscience, vol. 2, pp. 67-77, 2002.

[10] Y. Ji, K. Ghosh, X. Z. Shu et al., "Electrospun threedimensional hyaluronic acid nanofibrous scaffolds," Biomaterials, vol. 27, no. 20, pp. 3782-3792, 2006.

[11] E. Piskin, "Biodegradable polymers as biomaterials," Journal of Biomaterials Science Polymer Edition, vol. 6, pp. 75-870, 1995. 
[12] N. Ashammakhi and P. Rokkanen, "Absorbable polyglycolide devices in trauma and bone surgery," Biomaterials, vol. 18, no. 1, pp. 3-9, 1997.

[13] S. W. Shalaby, "Bioabsorbable polymers," in Encyclopedia of Pharmceutical Technology, J. Swarbrick and J. C. Boylan, Eds., vol. 1, pp. 465-476, 1988.

[14] S. J. Holland and B. J. Tighe, "Biodegradable polymers," in Advances in Pharmaceutical Science, vol. 6, pp. 101-164, Academic Press, London, UK, 1992.

[15] T. Hayashi, "Biodegradable polymers for biomedical uses," Progress in Polymer Science (Oxford), vol. 19, no. 4, pp. 663702, 1994.

[16] J. Kohn and R. Langer, "Bioresorbable and bioerodible materials," in An Introduction To Materials in Medicine, B. D. Ratner, A. S. Hoffman, F. J. Schoen, and J. E. Lemon, Eds., pp. 65-73, Academic Press, San Diego, Calif, USA, 1997.

[17] J. S. Temenoff and A. G. Mikos, "Injectable biodegradable materials for orthopedic tissue engineering," Biomaterials, vol. 21, no. 23, pp. 2405-2412, 2000.

[18] K. A. Athanasiou, G. G. Niederauer, and C. M. Agrawal, "Sterilization, toxicity, biocompatibility and clinical applications of polylactic acid/polyglycolic acid copolymers," Biomaterials, vol. 17, no. 2, pp. 93-102, 1996.

[19] L. L. Hench and J. M. Polak, "Third-generation biomedical materials," Science, vol. 295, no. 5557, pp. 1014-1017, 2002.

[20] G. D. Prestwich and H. Matthew, "Hybrid, composite, and complex biomaterials," Annals of the New York Academy of Sciences, vol. 961, pp. 106-108, 2002.

[21] X. Liu and P. X. Ma, "Polymeric scaffolds for bone tissue engineering," Annals of Biomedical Engineering, vol. 32, no. 3, pp. 477-486, 2004.

[22] S. L. Ishaug, G. M. Crane, M. J. Miller, A. W. Yasko, M. J. Yaszemski, and A. G. Mikos, "Bone formation by threedimensional stromal osteoblast culture in biodegradable polymer scaffolds," Journal of Biomedial Materials Research, vol. 36, pp. 17-28, 1997.

[23] S. L. Ishaug-Riley, G. M. Crane, A. Gurlek et al., "Ectopic bone formation by marrow stromal osteoblast transplantation using poly(DL-lactic-co-glycolic acid) foams implanted into the rat mesentery," Journal of Biomedial Materials Research, vol. 36, pp. 1-8, 1997.

[24] C. A. Vacanti and J. P. Vacanti, "Bone and cartilage reconstruction with tissue engineering approaches," Otolaryngologic Clinics of North America, vol. 27, no. 1, pp. 263-276, 1994.

[25] R. Y. Zhang and P. X. Ma, "Poly(alpha-hydroxyl acids) hydroxyapatite porous composites for bone-tissue engineering. I. Preparation and morphology," Journal of Biomedial Materials Research, vol. 44, pp. 446-455, 1999.

[26] P. X. Ma, R. Y. Zhang, G. Z. Xiao, and R. Franceschi, "Engineering new bone tissue in vitro on highly porous poly(alpha-hydroxyl acids)/hydroxyapatite composite scaffolds," Journal of Biomedial Materials Research, vol. 54, pp. 284-293, 2001.

[27] P. K. D. V. Yarlagadda, M. Chandrasekharan, and J. Y. M. Shyan, "Recent advances and current developments in tissue scaffolding," Bio-Medical Materials and Engineering, vol. 15, no. 3, pp. 159-177, 2005.

[28] H. Hermawan and D. Mantovani, "Degradable metallic biomaterials: the concept, current developments and future directions," Minerva Biotecnologica, vol. 21, no. 4, pp. 207216, 2009.
[29] C. Di Mario, H. Griffiths, O. Goktekin et al., "Drug-eluting bioabsorbable magnesium stent," Journal of Interventional Cardiology, vol. 17, no. 6, pp. 391-395, 2004.

[30] P. Peeters, M. Bosiers, J. Verbist, K. Deloose, and B. Heublein, "Preliminary results after application of absorbable metal stents in patients with critical limb ischemia," Journal of Endovascular Therapy, vol. 12, no. 1, pp. 1-5, 2005.

[31] F. Witte, V. Kaese, H. Haferkamp et al., "In vivo corrosion of four magnesium alloys and the associated bone response," Biomaterials, vol. 26, no. 17, pp. 3557-3563, 2005.

[32] R. Waksman, R. Pakala, P. K. Kuchulakanti et al., "Safety and efficacy of bioabsorbable magnesium alloy stents in porcine coronary arteries," Catheterization and Cardiovascular Interventions, vol. 68, no. 4, pp. 607-617, 2006.

[33] A. C. Hänzi, A. S. Sologubenko, and P. J. Uggowitzer, "Design strategy for microalloyed ultra-ductile magnesium alloys for medical applications," Materials Science Forum, vol. 618-619, pp. 75-82, 2009.

[34] E. Zhang and L. Yang, "Microstructure, mechanical properties and bio-corrosion properties of $\mathrm{Mg}-\mathrm{Zn}-\mathrm{Mn}-\mathrm{Ca}$ alloy for biomedical application," Materials Science and Engineering A, vol. 497, no. 1-2, pp. 111-118, 2008.

[35] Z. Li, X. Gu, S. Lou, and Y. Zheng, "The development of binary $\mathrm{Mg}-\mathrm{Ca}$ alloys for use as biodegradable materials within bone," Biomaterials, vol. 29, no. 10, pp. 1329-1344, 2008.

[36] M. Peuster, P. Wohlsein, M. Brügmann et al., "A novel approach to temporary stenting: degradable cardiovascular stents produced from corrodible metal-results 6-18 months after implantation into New Zealand white rabbits," Heart, vol. 86, no. 5, pp. 563-569, 2001.

[37] M. Peuster, C. Hesse, T. Schloo, C. Fink, P. Beerbaum, and C. von Schnakenburg, "Long-term biocompatibility of a corrodible peripheral iron stent in the porcine descending aorta," Biomaterials, vol. 27, no. 28, pp. 4955-4962, 2006.

[38] H. Hermawan, H. Alamdari, D. Mantovani, and D. Dubé, "Iron-manganese: new class of metallic degradable biomaterials prepared by powder metallurgy," Powder Metallurgy, vol. 51, no. 1, pp. 38-45, 2008.

[39] M. Schinhammer, A. C. Hänzi, J. F. Löffler, and P. J. Uggowitzer, "Design strategy for biodegradable Fe-based alloys for medical applications," Acta Biomaterialia, vol. 6, no. 5, pp. 1705-1713, 2010.

[40] J. Farack, C. Wolf-Brandstetter, S. Glorius et al., "The effect of perfusion culture on proliferation and differentiation of human mesenchymal stem cells on biocorrodible bone replacement material," Materials Science and Engineering B, vol. 176, pp. 1767-1772, 2011.

[41] F. Witte, V. Kaese, H. Haferkamp et al., "In vivo corrosion of four magnesium alloys and the associated bone response," Biomaterials, vol. 26, no. 17, pp. 3557-3563, 2005.

[42] R. M. Ginde and R. K. Gupta, "In vitro chemical degradation of poly(glycolic acid) pellets and fibers," Journal of Applied Polymer Science, vol. 33, no. 7, pp. 2411-2429, 1987.

[43] Y. Gong, Q. Zhou, C. Gao, and J. Shen, "In vitro and in vivo degradability and cytocompatibility of poly(l-lactic acid) scaffold fabricated by a gelatin particle leaching method," Acta Biomaterialia, vol. 3, no. 4, pp. 531-540, 2007.

[44] A. M. Reed and D. K. Gilding, "Biodegradable polymers for use in surgery-poly(glycolic)/poly(Iactic acid) homo and copolymers: 2. In vitro degradation," Polymer, vol. 22, no. 4, pp. 494-498, 1981. 
[45] J. J. Yoon and T. G. Park, "Degradation behaviors of biodegradable macroporous scaffolds prepared by gas foaming of effervescent salts," Journal of Biomedial Materials Research., vol. 55, pp. 401-408, 2001.

[46] T. Yoshioka, F. Kamada, N. Kawazoe, T. Tateishi, and G. Chen, "Structural changes and biodegradation of PLLA, PCL, and PLGA sponges during in vitro incubation," Polymer Engineering and Science, vol. 50, no. 10, pp. 1895-1903, 2010.

[47] A. W. T. Shum and A. F. T. Mak, "Morphological and biomechanical characterization of poly(glycolic acid) scaffolds after in vitro degradation," Polymer Degradation and Stability, vol. 81, no. 1, pp. 141-149, 2003.

[48] L. Wu and J. Ding, "In vitro degradation of threedimensional porous poly(D,L-lactide-co- glycolide) scaffolds for tissue engineering," Biomaterials, vol. 25, no. 27, pp. 5821-5830, 2004.

[49] L. Xu, Z. C. Xiong, D. Yang, L. F. Zhang, J. Chang, and C. D. Xiong, "Preparation and in vitro degradation of novel bioactive polylactide/wollastonite scaffolds," Journal of Applied Polymer Science, vol. 114, no. 6, pp. 3396-3406, 2009.

[50] L. Tan, M. Gong, F. Zheng, B. Zhang, and K. Yang, "Study on compression behavior of porous magnesium used as bone tissue engineering scaffolds," Biomedical Materials, vol. 4, no. 1, Article ID 015016, 2009.

[51] T. L. Nguyen, M. P. Staiger, G. J. Dia, and s T. B. F. Woodfield, "A novel manufacturing route for fabrication of topologically-ordered porous magnesium scaffolds," Advanced Engineering Materials, vol. 13, pp. 872-881, 2011.

[52] N. E. L. Saris, E. Mervaala, H. Karppanen, J. A. Khawaja, and A. Lewenstam, "Magnesium: an update on physiological, clinical and analytical aspects," Clinica Chimica Acta, vol. 294, no. 1-2, pp. 1-26, 2000.

[53] J. Vormann, "Magnesium: nutrition and metabolism," Molecular Aspects of Medicine, vol. 24, no. 1-3, pp. 27-37, 2003.

[54] T. Okuma, "Magnesium and bone strength," Nutrition, vol. 17, no. 7-8, pp. 679-680, 2001.

[55] A. Hartwig, "Role of magnesium in genomic stability," Mutation Research, vol. 475, pp. 113-134, 2001.

[56] F. I. Wolf and A. Cittadini, "Chemistry and biochemistry of magnesium," Molecular Aspects of Medicine, vol. 24, no. 1-3, pp. 3-9, 2003.

[57] Merk, "Water, electrolyte mineral and acid/base metabolism," in Section 2. Endocrine \& Metabolic Disorders. Merk Manual of Diagnosis and Therapy, chapter 12, 2012, http://www. newtreatments.org/loadlocal.php?hid=998.

[58] F. Witte, H. A. Crostack, J. Nellesen, and F. Beckmann, "Characterization of degradable magnesium alloys as orthopaedic implant material by synchrotron-radiationbased microtomography," 2012, http://www-hasylab.desy.de /science/annual_reports/2001_report/part1/contrib/47/5461. pdf.

[59] L. Xu, G. Yu, E. Zhang, F. Pan, and K. Yang, "In vivo corrosion behavior of $\mathrm{Mg}-\mathrm{Mn}-\mathrm{Zn}$ alloy for bone implant application," Journal of Biomedical Materials Research-Part A, vol. 83, no. 3, pp. 703-711, 2007.

[60] F. Witte, H. Ulrich, M. Rudert, and E. Willbold, "Biodegradable magnesium scaffolds: part I: appropriate inflammatory response," Journal of Biomedical Materials Research-Part A, vol. 81, no. 3, pp. 748-756, 2007.

[61] X. N. Gu, W. R. Zhou, Y. F. Zheng, Y. Liu, and Y. X. Li, "Degradation and cytotoxicity of lotus-type porous pure magnesium as potential tissue engineering scaffold material," Materials Letters, vol. 64, no. 17, pp. 1871-1874, 2010.
[62] H. Zreiqat, C. R. Howlett, A. Zannettino et al., "Mechanisms of magnesium-stimulated adhesion of osteoblastic cells to commonly used orthopaedic implants," Journal of Biomedical Materials Research, vol. 62, no. 2, pp. 175-184, 2002.

[63] Y. Yamasaki, Y. Yoshida, M. Okazaki et al., "Synthesis of functionally graded $\mathrm{MgCO}_{3}$ apatite accelerating osteoblast adhesion," Journal of Biomedical Materials Research, vol. 62, no. 1, pp. 99-105, 2002.

[64] Y. Yamasaki, Y. Yoshida, M. Okazaki et al., "Action of $\mathrm{FGMgCO}_{3} \mathrm{Ap}$-collagen composite in promoting bone formation," Biomaterials, vol. 24, no. 27, pp. 4913-4920, 2003.

[65] M. P. Staiger, A. M. Pietak, J. Huadmai, and G. Dias, "Magnesium and its alloys as orthopedic biomaterials: a review," Biomaterials, vol. 27, no. 9, pp. 1728-1734, 2006.

[66] X. N. Gu and Y. F. Zheng, "A review on magnesium alloys as biodegradable materials," Frontiers of Materials Science in China, vol. 4, no. 2, pp. 111-115, 2010.

[67] X. Gu, Y. Zheng, Y. Cheng, S. Zhong, and T. Xi, "In vitro corrosion and biocompatibility of binary magnesium alloys," Biomaterials, vol. 30, no. 4, pp. 484-498, 2009.

[68] H. Wang, Y. Estrin, and Z. Zúberová, "Bio-corrosion of a magnesium alloy with different processing histories," Materials Letters, vol. 62, no. 16, pp. 2476-2479, 2008.

[69] Z. Li, X. Gu, S. Lou, and Y. Zheng, "The development of binary $\mathrm{Mg}-\mathrm{Ca}$ alloys for use as biodegradable materials within bone," Biomaterials, vol. 29, no. 10, pp. 1329-1344, 2008.

[70] J. Black and G. Hastings, Handbook of Biomaterial Properties, Chapman \& Hall, London, UK, 1998.

[71] ASTM, "Standard specification for wrought 18chromium14nickel-2.5molybdenum stainless steel bar and wire for surgical implants (UNS S31673)," Tech. Rep. F138, ASTM International, West Conshohocken, Pa, USA, 2003.

[72] ASM, ASM Handbook: Properties and Selection: Nonferrous Alloys \& Special Purpose Materials, Vol. 2, ASM International, Materials Park, Ohio, USA, 2005.

[73] ASTM, "Standard specification for magnesium-alloy sand castings," Tech. Rep. B80, ASTM International, West Conshohocken, Pa, USA, 2001.

[74] F. Witte, N. Hort, C. Vogt et al., "Degradable biomaterials based on magnesium corrosion," Current Opinion in Solid State and Materials Science, vol. 12, no. 5-6, pp. 63-72, 2008.

[75] B. A. Shaw, ASM Handbook Volume 13A: Corrosion: Fundamentals, Testing and Protection, Edited by D. Stephen, ASM International, Materials Park, Ohio, USA, 2003.

[76] A. L. Lambotte, "Utilisation du magnesium comme materiel perdu dans l'osteosynthese," Bulletins et Mémoires de la Société de Chirurgie de Paris, vol. 28, pp. 1325-1359, 1932.

[77] V. V. Troitskii and D. N. Tsitrin, "The resorbing metallic alloy 'Osteosinthezit'as material for fastening broken bone," Khirurgiia, vol. 8, pp. 41-45, 1944.

[78] E. D. McBride, "Absorbable metal for bone surgery," The Journal of the American Medical Association, vol. 111, pp. 2464-2467, 1938.

[79] J. Verbrugge, "Le Materiel Metallique Resorbable En Chirurgie Osseuse," La Presse Médicale, vol. 23, pp. 460-465, 1934.

[80] G. B. Stroganov, E. Savitsky, T. Mikhailovich, M. Nina, V. Terekhova, and V. Fedorovna, "Magnesium-base alloys for use in bone surgery," US Patent no. 3, 687, 135, 1972.

[81] M. B. Kannan and R. K. S. Raman, "In vitro degradation and mechanical integrity of calcium-containing magnesium alloys in modified-simulated body fluid," Biomaterials, vol. 29, no. 15, pp. 2306-2314, 2008. 
[82] L. Xu, E. Zhang, D. Yin, S. Zeng, and K. Yang, "In vitro corrosion behaviour of $\mathrm{Mg}$ alloys in a phosphate buffered solution for bone implant application," Journal of Materials Science, vol. 19, no. 3, pp. 1017-1025, 2008.

[83] X. N. Gu, W. Zheng, Y. Cheng, and Y. F. Zheng, "A study on alkaline heat treated $\mathrm{Mg}-\mathrm{Ca}$ alloy for the control of the biocorrosion rate," Acta Biomaterialia, vol. 5, no. 7, pp. 27902799, 2009.

[84] F. Witte, J. Fischer, J. Nellesen et al., "In vivo corrosion and corrosion protection of magnesium alloy LAE442," Acta Biomaterialia, vol. 6, no. 5, pp. 1792-1799, 2010.

[85] M. B. Kannan and L. Orr, "In vitro mechanical integrity of hydroxyapatite coated magnesium alloy," Biomedical Materials, vol. 6, Article ID 045003, 2011.

[86] J. H. Jo, B.G. Kang, K.S. Shin et al., "Hydroxyapatite coating on magnesium with $\mathrm{MgF}_{2}$ interlayer for enhanced corrosion resistance and biocompatibility," Journal of Materials Science, vol. 22, no. 11, pp. 2437-2447, 2011.

[87] L. Xu, E. Zhang, and K. Yang, "Phosphating treatment and corrosion properties of $\mathrm{Mg}-\mathrm{Mn}-\mathrm{Zn}$ alloy for biomedical application," Journal of Materials Science, vol. 20, no. 4, pp. 859-867, 2009.

[88] X. N. Gu, Y. F. Zheng, Q. X. Lan et al., "Surface modification of an $\mathrm{Mg}-1 \mathrm{Ca}$ alloy to slow down its biocorrosion by chitosan," Biomedical Materials, vol. 4, no. 4, Article ID 044109, 2009.

[89] Y. Kuboki, H. Takita, D. Kobayashi, E. Tsuruga, M. Inoue, and M. Murata, "BMP-induced osteogenesis on the surface of hydroxyapatite with geometrically feasible and nonfeasible structures: topology of osteogenesis," Journal of Biomedial Materials Research, vol. 39, pp. 190-199, 1998.

[90] M. Svehla, P. Morberg, B. Zicat, W. Bruce, D. Sonnabend, and W. R. Walsh, "Morphometric and mechanical evaluation of titanium implant integration: comparison of five surface structures," Journal of Biomedial Materials Research, pp. 1522,2000

[91] C. E. Wen, Y. Yamada, K. Shimojima, Y. Chino, H. Hosokawa, and M. Mabuchi, "Compressibility of porous magnesium foam: dependency on porosity and pore size," Materials Letters, vol. 58, no. 3-4, pp. 357-360, 2004.

[92] H. Zhuang, Y. Han, and A. Feng, "Preparation, mechanical properties and in vitro biodegradation of porous magnesium scaffolds," Materials Science and Engineering C, vol. 28, no. 8, pp. 1462-1466, 2008.

[93] C. E. Wen, M. Mabuchi, Y. Yamada, K. Shimojima, Y. Chino, and T. Asahina, "Processing of biocompatible porous Ti and Mg," Scripta Materialia, vol. 45, no. 10, pp. 1147-1153, 2001.

[94] Y. Yamada, K. Shimojima, Y. Sakaguchi et al., "Processing of cellular magnesium materials," Advanced Engineering Materials, vol. 2, no. 4, pp. 184-187, 2000.

[95] P. E. DeGarmo, Materials and Processes in Manufacturing, Collin Macmillan, New York, NY, USA, 5th edition, 1979.

[96] L. Gibson and M. Ashby, Cellular Solids: Structure and Properties, Pergamon Press, Sydney, Australia, 1988.

[97] L. Gibson and M. Ashby, Solids: Structure and Properties, Pergamon Press, Sydney, Australia, 1988.

[98] L. J. Gibson, "The mechanical behaviour of cancellous bone," Journal of Biomechanics, vol. 18, no. 5, pp. 317-328, 1985.

[99] J. L. Simon, T. D. Roy, J. R. Parsons et al., "Engineered cellular response to scaffold architecture in a rabbit trephine defect," Journal of Biomedical Materials Research-Part A, vol. 66, no. 2, pp. 275-282, 2003.
[100] V. S. Deshpande, M. F. Ashby, and N. A. Fleck, "Foam topology: bending versus stretching dominated architectures," Acta Materialia, vol. 49, no. 6, pp. 1035-1040, 2001.

[101] L. P. Lefebvre, J. Banhart, and D. C. Dunand, "Porous metals and metallic foams: current status and recent developments," Advanced Engineering Materials, vol. 10, no. 9, pp. 775-787, 2008.

[102] T. Adachi, Y. Osako, M. Tanaka, M. Hojo, and S. J. Hollister, "Framework for optimal design of porous scaffold microstructure by computational simulation of bone regeneration," Biomaterials, vol. 27, no. 21, pp. 3964-3972, 2006.

[103] C. Y. Lin, C. C. Hsiao, P. Q. Chen, and S. J. Hollister, "Interbody fusion cage design using integrated global layout and local microstructure topology optimization," Spine, vol. 29, no. 16, pp. 1747-1754, 2004.

[104] S. J. Hollister, "Scaffold design and manufacturing: from concept to clinic," Advanced Materials, vol. 21, no. 32-33, pp. 3330-3342, 2009.

[105] M. P. Staiger, I. Kolbeinsson, N. T. Kirkland, T. Nguyen, G. Dias, and T. B. F. Woodfield, "Synthesis of topologicallyordered open-cell porous magnesium," Materials Letters, vol. 64, no. 23, pp. 2572-2574, 2010.

[106] N. T. Kirkland, I. Kolbeinsson, T. Woodfield, G. J. Dias, and M. P. Staiger, "Synthesis and properties of topologically ordered porous magnesium," Materials Science and Engineering B, vol. 176, no. 20, pp. 1666-1672, 2011.

[107] F. Witte, J. Reifenrath, P. P. Müller et al., "Cartilage repair on magnesium scaffolds used as a subchondral bone replacement," Materialwissenschaft und Werkstofftechnik, vol. 37, no. 6, pp. 504-508, 2006.

[108] R. Tunold, H. Holtan, M. B. H. Berge, A. Lasson, and R. Steen-Hansen, "The corrosion of magnesium in aqueous solution containing chloride ions," Corrosion Science, vol. 17, no. 4, pp. 353-365, 1977.

[109] J. Światowska, P. Volovitch, and K. Ogle, "The anodic dissolution of $\mathrm{Mg}$ in $\mathrm{NaCl}$ and $\mathrm{Na}_{2} \mathrm{SO}_{4}$ electrolytes by atomic emission spectroelectrochemistry," Corrosion Science, vol. 52, no. 7, pp. 2372-2378, 2010.

[110] W. D. Müller, M. L. Nascimento, M. Zeddies, M. Córsico, L. M. Gassa, and M. A. F. L. de Mele, "Magnesium and its alloys as degradable biomaterials. Corrosion studies using potentiodynamic and EIS electrochemical techniques," Materials Research, vol. 10, no. 1, pp. 5-10, 2007.

[111] J. Wei, J. Jia, F. Wu et al., "Hierarchically microporous/macroporous scaffold of magnesium-calcium phosphate for bone tissue regeneration," Biomaterials, vol. 31, no. 6, pp. 1260-1269, 2010.

[112] J. Banhart, "Manufacture, characterisation and application of cellular metals and metal foams," Progress in Materials Science, vol. 46, no. 6, pp. 559-632, 2001.

[113] G. Ryan, A. Pandit, and D. P. Apatsidis, "Fabrication methods of porous metals for use in orthopaedic applications," Biomaterials, vol. 27, no. 13, pp. 2651-2670, 2006.

[114] M. Fontecave and J. L. Pierre, "Iron: metabolism, toxicity and therapy," Biochimie, vol. 75, no. 9, pp. 767-773, 1993.

[115] P. P. Mueller, T. May, A. Perz, H. Hauser, and M. Peuster, "Control of smooth muscle cell proliferation by ferrous iron," Biomaterials, vol. 27, no. 10, pp. 2193-2200, 2006.

[116] G. Song, "Control of biodegradation of biocompatable magnesium alloys," Corrosion Science, vol. 49, no. 4, pp. 1696-1701, 2007.

[117] G. Sangiorgi, G. Melzi, P. Agostoni et al., "Engineering aspects of stents design and their translation into clinical 
practice," Annali dell'Istituto Superiore di Sanita, vol. 43, no. 1, pp. 89-100, 2007.

[118] H. Hermawan, D. Dubé, and D. Mantovani, "Degradable metallic biomaterials: design and development of Fe-Mn alloys for stents," Journal of Biomedical Materials ResearchPart A, vol. 93, no. 1, pp. 1-11, 2010.

[119] P. Quadbeck, R. Hauser, K. Kummel et al., "Iron based cellular metals for degradable synthetic bone replacement," in Proceedings of the Powder Metallurgy World Congress (PM '10), Florence, Italy, 2010.

[120] J. Kováčik, "The tensile behaviour of porous metals made by GASAR process," Acta Materialia, vol. 46, no. 15, pp. 54135422, 1998.

[121] S. K. Hyun, T. Ikeda, and H. Nakajima, "Fabrication of lotustype porous iron and its mechanical properties," Science and Technology of Advanced Materials, vol. 5, no. 1-2, pp. 201205, 2004.

[122] T. Murakami, K. Ohara, T. Narushima, and C. Ouchi, "Development of a new method for manufacturing iron foam using gases generated by reduction of iron oxide," Materials Transactions, vol. 48, no. 11, pp. 2937-2944, 2007.

[123] C. S. Y. Jee, N. Özgüven, Z. X. Guo, and J. R. G. Evans, "Preparation of high porosity metal foams," Metallurgical and Materials Transactions B, vol. 31, no. 6, pp. 1345-1352, 2000.

[124] Z. Liu, T. Fan, W. Zhang, and D. Zhang, "The synthesis of hierarchical porous iron oxide with wood templates," Microporous and Mesoporous Materials, vol. 85, no. 1-2, pp. 85-88, 2005. 

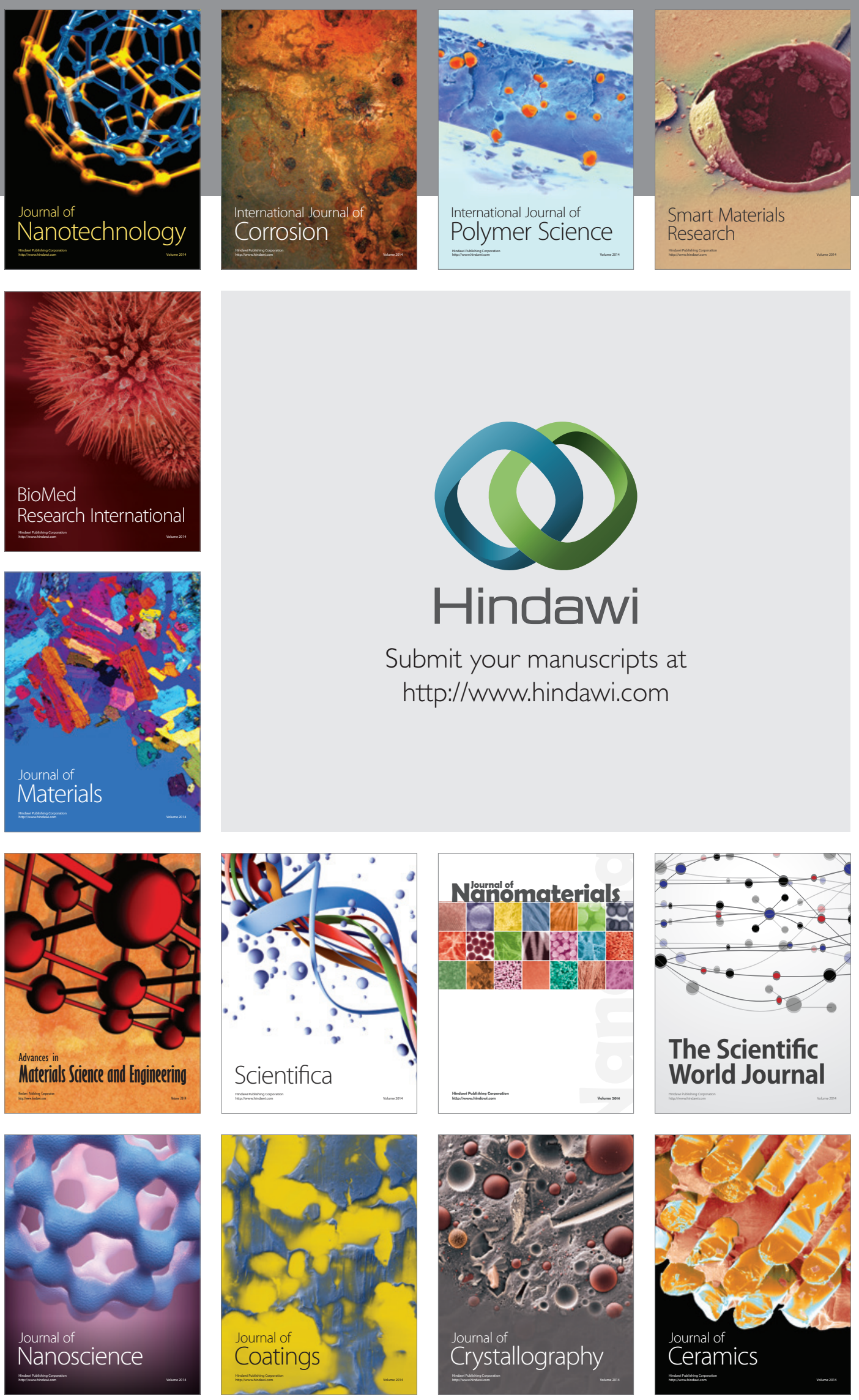

The Scientific World Journal

Submit your manuscripts at

http://www.hindawi.com

\section{World Journal}

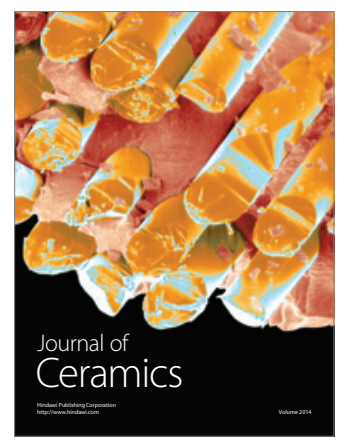

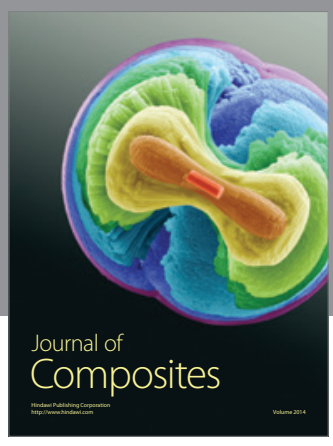
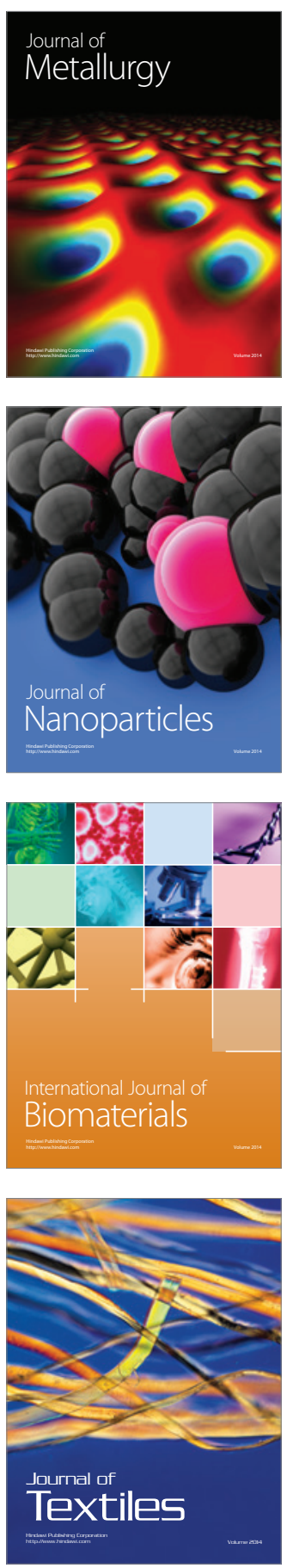